\title{
Identification and characterization of mechanistically distinct inducers of $\gamma$-globin transcription
}

\author{
John D. Haley ${ }^{\mathrm{a}, *}$, David E. Smith ${ }^{\mathrm{a}}$, Janine Schwedes ${ }^{\mathrm{a}}$, Richard Brennan ${ }^{\mathrm{a}}$, Cedric Pearce ${ }^{\mathrm{a}}$, \\ Claudia Moore ${ }^{\mathrm{a}}$, Faye Wang ${ }^{\mathrm{a}}$, Fillipo Petti ${ }^{\mathrm{a}}$, Frank Grosveld ${ }^{\mathrm{b}}$, Stephen M. Jane ${ }^{\mathrm{c}}$, \\ Constance T. Noguchi ${ }^{\mathrm{d}}$, Alan N. Schechter ${ }^{\mathrm{d}}$ \\ ${ }^{a}$ OSI Pharmaceuticals Inc., Farmingdale, NY 11735, USA \\ ${ }^{\mathrm{b}}$ Erasmus University, Rotterdam, The Netherlands \\ ${ }^{\mathrm{c}}$ Rotary Bone Marrow Research Laboratories, Royal Melbourne Hospital Research Foundation, Parkville, Vic., Australia \\ ${ }^{\mathrm{d}}$ National Institutes of Health, NIDDK, Bethesda, MD, USA
}

Received 9 April 2003; accepted 5 July 2003

\begin{abstract}
Inhibition of $\mathrm{HbS}$ polymerization is a major target for therapeutic approaches in sickle cell anemia. Toward this goal, initial efforts at pharmacological elevation of fetal hemoglobin $(\mathrm{HbF})$ has shown therapeutic efficacy. In order to identify well-tolerated, novel agents that induce $\mathrm{HbF}$ in patients, we developed a high-throughput screening approach based on induction of $\gamma$-globin gene expression in erythroid cells. We measured $\gamma$-globin transcription in K562 cells transfected with either $\gamma$ promoter elements fused with the locus control region hypersensitivity site 2 and luciferase reporter gene (HS2 $\gamma$ ) or a $\beta$-yeast artificial chromosome in which the luciferase reporter gene was recombined into the $\gamma$-globin coding sequences ( $\gamma$ YAC). Corresponding pharmacological increases in HbF protein were confirmed in both K562 cells and in human primary erythroid progenitor cells. Approximately 186,000 defined chemicals and fungal extracts were evaluated for their ability to increase $\gamma$ gene transcription in either HS $2 \gamma$ or $\gamma$ YAC models. Eleven distinct classes of compounds were identified, the majority of which were active within $24-48 \mathrm{hr}$. The short chain hydroxamate-containing class generally exhibited delayed maximal activity, which continued to increase transcription up to $120 \mathrm{hr}$. The cyclic tetrapeptide OSI-2040 and the hydroxamates were shown to have histone deacetylase inhibitory activity. In primary hematopoietic progenitor cell cultures, OSI-2040 increased $\mathrm{HbF}$ by 4.5 -fold at a concentration of only $40 \mathrm{nM}$, comparable to the effects of hydroxyurea at $100 \mu \mathrm{M}$. This screening methodology successfully identifies active compounds for further mechanistic and preclinical evaluation as potential therapeutic agents for sickle cell anemia.
\end{abstract}

(C) 2003 Elsevier Inc. All rights reserved.

Keywords: Sickle disease; $\gamma$-Globin transcription; Histone deacetylase; Globin-switching

${ }^{*}$ Corresponding author. Tel.: +1-631-962-0709; fax: +1-631-845-5671.

E-mail address: jhaley@osip.com (J.D. Haley).

Abbreviations: HS, hypersensitivity site; YAC, yeast artificial chromosome; $\mathrm{HbF}$, fetal hemoglobin; HbA, adult hemoglobin; HbS, sickle hemoglobin; HPFH, hereditary persistence of fetal hemoglobin; MEL, murine erythroleukemia; MTT, 3-[4,5 dimethylthiazol-2-yl-]-2,5-diphenyl tetrazolium bromide; HRP, horseradish peroxidase; FCS, fetal calf serum; $\alpha$ MEM, $\alpha$-modified Eagle's media; DTT, 1,4-dithiothreitol; PMSF, phenylmethylsulfonylfluoride; TMB, 3,3',5,5'-tetramethylbenzidine; SCF, stem cell factor; GADD153, growth arrest and DNA damage 153; GST Ya, glutathione-S-transferase Ya; HMO, heme mono-oxygenase; HSP70, heat shock protein 70; HIF-1 RE, hypoxia inducible factor 1 response element; NF-AT RE, nuclear factor AT response element; NF- $\mathrm{BB}$ RE, nuclear factor kappa-B response element; XRE, xenobiotic element; DMEM, Dulbecco modified Eagle's medium; ANOVA, analysis of variance; $\mathrm{EC}_{50}$, half-maximal effective concentration; $\mathrm{IC}_{50}$, half-maximal inhibitory concentration; PHA, proprionic hydroxamic acid; MMS, methane methyl sulfonate; $\mathrm{AH}$, aryl hydrocarbon; RT-PCR, reverse transcriptase-polymerase chain reaction; HDA, histone deacetylase; ELISA, enzyme-linked immunosorbent assay.

\section{Introduction}

Through large-scale robotic screening we have sought to identify and characterize, at the molecular level, chemical compounds which increase expression of fetal $\gamma$-globin. $\mathrm{HbF}$ augmenting agents are useful in the management of sickle cell anemia and $\beta$-thalassemias to compensate for defects in the $\beta$-chain of adult hemoglobin ( $\mathrm{HbA})$. Sickle cell disease results from a change at codon 6 of the adult $\beta$ globin gene so that a glutamate is replace by a valine $(\mathrm{HbA}$ to $\mathrm{HbS}$ ) and afflicts 1 in 400 Afro-Americans. The altered $\beta$-globin protein aggregates to produce an irreversible deformation of red blood cell morphology and a vasoocculsive disease with severe morbidity [1]. $\beta$-Thalassemias arise from a wide variety of genetic mutations which 
result in either the loss or reduced expression of the $\beta$ globin gene. Thalassemia major, also known as Cooley's anemia, is characterized by marked anemia, severe hemolysis, and ineffective erythropoiesis. Worldwide 240 million people are heterozygous for these hemoglobinopathies and these disorders are being actively selected for by vivax and falciparum malaria [2].

The human $\beta$-like globin genes $(\varepsilon, \gamma, \delta, \beta)$ and the sequence designated as the locus control region (LCR) are clustered on $\sim 100 \mathrm{~kb}$ of chromosome 11 (Fig. 1).
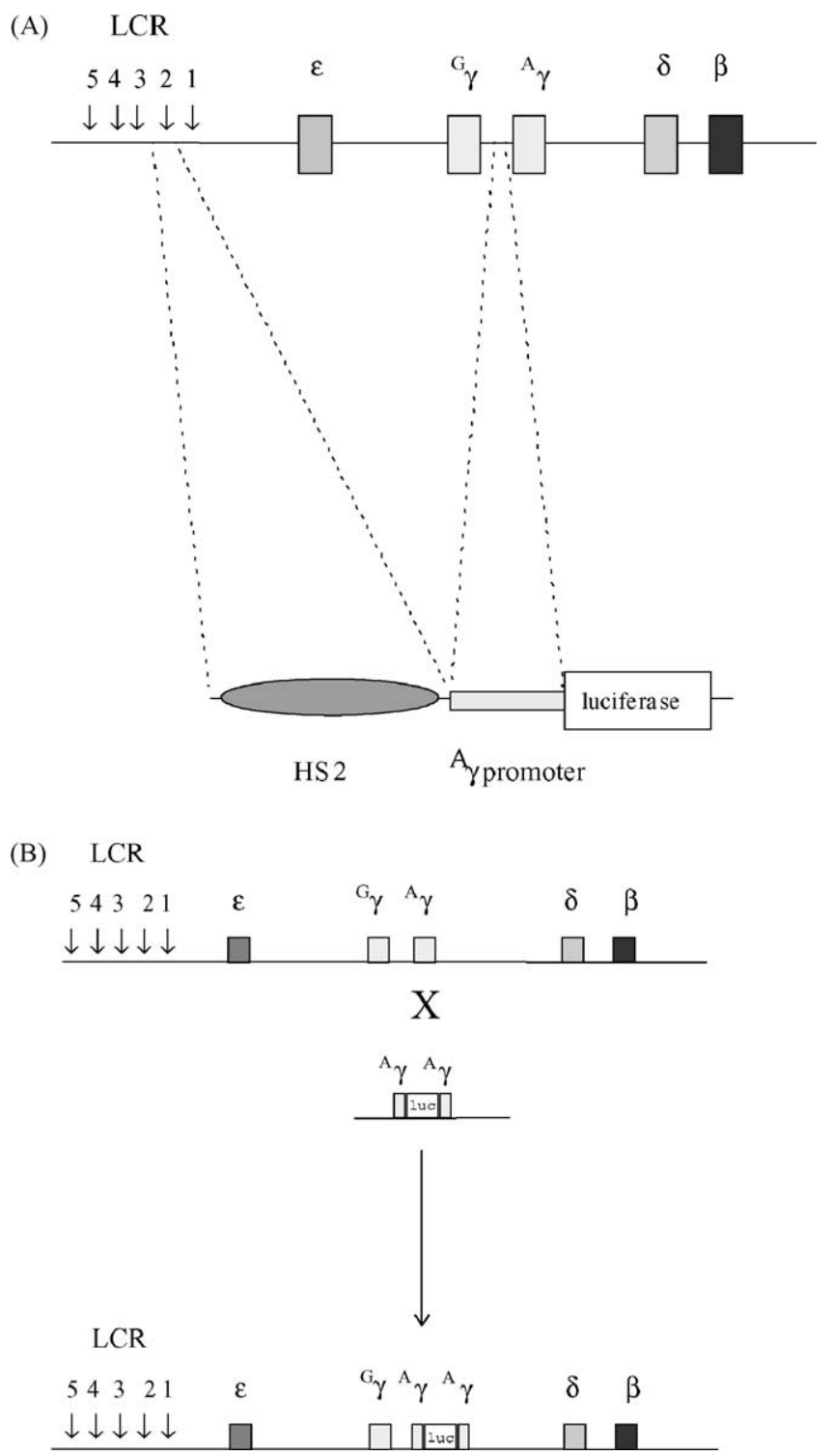

Fig. 1. (A) K562/HS2 $\gamma$ luciferase screening construct. LCR hypersensitive site 2 (HS2) was linked to the $\gamma$-globin proximal promoter and inserted $5^{\prime}$ to a luciferase reporter gene from $P$. pyralis. TK-neo was added and the resulting plasmid DNA was linearized and stably integrated in K562 cells by electroporation. (B) K562/ $\gamma$ YAC luciferase screening construct. A luciferase reporter gene was recombined into the $\mathrm{A} \gamma$-globin gene within a $540 \mathrm{~kb}$ yeast artificial chromosome (YAC; Groveld et al., 1996). Recombination was performed such that the ATG of luciferase displaced the ATG of A $\gamma$. The resulting luciferase- 'tagged' $\gamma$-globin gene was stably integrated in K562 cells by spheroplast fusion.
During embryonic and fetal development, globin genes are expressed in a temporal and tissue-specific fashion, which requires switches in both $\alpha$ - and $\beta$-like globin expression so that sequential appearance of embryonic $\left(\zeta_{2} \varepsilon_{2}, \alpha_{2} \varepsilon_{2}\right.$, and $\left.\zeta_{2} \gamma_{2}\right)$, then fetal $\left(\alpha_{2} \gamma_{2}\right)$, and then finally the adult forms $\left(\alpha_{2} \beta_{2}\right.$ and $\left.\alpha_{2} \delta_{2}\right)$ of hemoglobin occur $[3,4]$. Developmental regulation of the $\beta$-globin gene cluster is mediated by several mechanisms. Sequences (enhancers and silencers) both within and immediately flanking the genes themselves confer tissue and temporal specificity [5-8]. A $20 \mathrm{~kb}$ region $5^{\prime}$ of the $\beta$-globin locus, termed the LCR, is defined by five major DNase I hypersensitive sites (HS-I to HS-V) and has been shown to be critical for high level, tissue-specific globin gene expression [9-11]. The individual genes of the $\beta$-globin locus compete for physical association with the LCR, most likely through the interaction of transcription factors which bind the LCR and the individual globin promoters $[12,13]$.

In man, there is compelling evidence, genetic and pharmaceutical, that increasing expression of $\gamma$-globin has clinical benefit in both sickle cell anemia and $\beta$ thalassemia $[14,15]$. In normal individuals, between 1 and 3\% of mature red blood cells express fetal $\gamma$-globin. In contrast, adults with an asymptomatic condition termed HPFH, exhibit high levels of fetal $\gamma$-globin. Based on such clinical studies, it has been calculated that an induction of $\gamma$-globin gene expression to approximately $10-20 \%$ (or a 3 - to 5 -fold increase from individual baseline) of the adult $\beta$-globin level will significantly ameliorate the symptoms of sickle cell disease [16]. While the cis-acting DNA elements required for $\gamma$-globin transcription and HPFH have been well defined [17-24], the identity of factor(s) which compete for these DNA elements and signaling pathways being modulated under physiological conditions of low and high $\mathrm{HbF}$ synthesis, remain unclear. Competition of linked $\gamma$ and $\beta$ genes appears to be mediated by multiple elements within the human $\gamma$-globin promoter [17] and likely requires recruitment of repressor factors [25] which in turn recruit histone deacetylases (HDAs).

Several pharmacological approaches seeking to up-regulate $\mathrm{HbF}$ have been developed. These include the DNA methyltransferase inhibitor $5^{\prime}$-aza-cytidine [26,27], the ribonucleotide reductase inhibitor hydroxyurea [28], short chain fatty acids, such as butyric acid [29], and a number of other cytostatic agents. The effective concentration of these agents can be variable from individual to individual and these agents can show steep dose-response profiles with relatively narrow margins of safety. As a result, we sought to identify new agents which augment $\mathrm{HbF}$, to better define mechanisms by which pharmacological increases in $\mathrm{HbF}$ may be afforded and asked the question whether compound cytotoxicity was a requirement for induction of $\gamma$-globin transcription. Cell-based $\gamma$-globin transcription assays combined with high-throughput screening (HTS) were used to evaluate $>186,000$ compounds and fungal 
extracts. Structurally distinct classes of compounds were identified which induce $\gamma$-globin transcription and $\mathrm{HbF}$ accumulation, through diverse mechanisms of action. The data support models where chromatin remodeling and/or delayed erythroid cell cycling can lead to increased $\mathrm{HbF}$ expression through both transcriptional and post-transcriptional mechanisms.

\section{Materials and methods}

\subsection{Identification of $\gamma$-globin-inducing compounds and extracts}

The HS2 enhancer element of the LCR and proximal promoter sequences from the $\gamma$-globin gene [30] were fused to the luciferase 'reporter' gene from $H$. pyralis [31]. The TK-neo gene, present in cis on the reporter plasmid, was used as the selectable marker for mammalian cell transfection. Human K562 cells, which display early erythroid and myeloid progenitor markers, were stably electroporated to express HS2 $\gamma$ luciferase. Luciferase'tagged' $\gamma$-globin yeast artificial chromosome (YAC; $\gamma$ YAC) was constructed as previously described [32] where the luciferase gene was recombined into YAC DNA $3^{\prime}$ of the $A \gamma$ promoter within the context of the full $\beta$-globin locus. $\gamma$ YAC DNA was introduced into K562 cells and MEL cells by protoplast fusion and cells selected for puromycin resistance. Individual clonal lines were evaluated by (i) basal luciferase expression; (ii) faithful integration of linear DNA as determined by Southern hybridization; and (iii) inducible regulation of the integrated reporter construct by hemin and 5-aza-cytidine (4to 6-fold for HS2 $\gamma$ and $>3$-fold for $\gamma$ YAC). Expression levels from multiple K562 lines expressing HS2 $\gamma$ or $\gamma$ YAC genes were suitable for HTS, while expression levels of $\gamma$ YAC in MEL-derived clones were insufficient.

Chemical compounds were synthesized as discrete compounds, dissolved in neat DMSO and were screened on an individual basis at a concentration of $\sim 12 \mu \mathrm{M}$. Fungal extracts were prepared by freeze drying the fermentation material, broth and mycelia together, followed by extraction with methanol. Extracts were dried and subjected to solvent fractionation to provide three crude fractions (water-methanol, chloroform, and hexane) which were tested for biological activity at a 1:4 dilution of the starting culture volume (N/4). Active fractions were further purified by reverse-phase HPLC. Full characterization of selected compounds was achieved using mass spectrometry and NMR techniques.

$\mathrm{K} 562 / \mathrm{HS} 2 \gamma$ and $\mathrm{K} 562 / \gamma \mathrm{YAC}$ cells were plated at 10,000 cells per well in phenol red-free RPMI-1640 media, $2 \%$ fetal calf serum (FCS; Hyclone), $20 \mathrm{mM} \mathrm{L-glutamine,}$ penicillin (100 units $/ \mathrm{mL})$, streptomycin $(100 \mu \mathrm{g} / \mathrm{mL})$, 20 mM HEPES, pH 7.4, in 96-well microtiter plates. Cells were induced with compound $(\sim 12 \mu \mathrm{M})$ or fungal extract
(N/4) for a period of $24 \mathrm{hr}$. The final compound solvent concentration was $0.2 \%$ DMSO, which was used as the negative control. The positive control was $1 \mu \mathrm{M}$ aza-cytidine. Upon completion of induction period, luciferase buffer was added to each well to achieve a final concentration of $100 \mathrm{mM}$ Tris-acetate, $\mathrm{pH} 7.9,20 \mathrm{mM}$ magnesium acetate, $2 \mathrm{mM}$ EGTA, $1 \%$ Brij 58, $100 \mathrm{mM} 2$ mercaptoethanol, $36 \mathrm{mM}$ ATP, $150 \mu \mathrm{M}$ luciferin. Cells were allowed to lyse for $5 \mathrm{~min}$ at room temperature after which the chemiluminescent signal was measured (Dynatech Lab ML1000-medium gain setting). A preliminary screen of approximately 5000 compounds was performed, incorporating internal controls on each microtiter plate. These studies defined criteria to accept or reject HTS data, requiring that: (1) penicillic acid or 5-aza-cytidine induced HS $2 \gamma$ reporter gene expression $>4$-fold or $\gamma$ YAC expression $>2$-fold; (2) that the baseline signal was $>0.05$ luminometer units; and (3) that the coefficient of variation of controls on each microtiter plate was $<20 \%$.

\subsection{Cytotoxicity assays}

MTT (3-[4,5 dimethylthiazol-2-yl-]-2,5-diphenyl tetrazolium bromide), a commonly used colorimetric substrate, was used to measure mitochondrial respiration in order to assess cell viability. Cells were plated as described for the luciferase reporter gene assays. After incubation with test compounds for 24 and $48 \mathrm{hr}, 20 \mu \mathrm{L}$ of $3 \mathrm{mg} / \mathrm{mL}$ MTT was added and cells incubated for $2 \mathrm{hr}$ at $37^{\circ}, 5 \% \mathrm{CO}_{2}$. One hundred microliters of $10 \%$ SDS was added to all wells for $4 \mathrm{hr}$ at $37^{\circ}$ to allow for lysis and solubilization of MTT. Mitochondrial conversion of MTT was assessed by measurement of light absorbance at $540 \mathrm{nM}$. Background (from the PBS control) was subtracted and the data expressed as \% inhibition of cell growth.

\subsection{HbF ELISA of K562 hypotonic lysates}

K562 cells were exposed in duplicate to compound for a period of 4 days. Cells were collected by centrifugation (1000 g; $5 \mathrm{~min}$ ), media aspirated, cells washed with PBS, and the cell pellet lysed in ice-cold $\mathrm{H}_{2} \mathrm{O}$ by vortexing for $\sim 40 \mathrm{~s}$. Nuclei were removed by centrifugation $(13,000 \mathrm{~g}$; $4^{\circ}$ for $\left.4 \mathrm{~min}\right)$. Cleared lysate was removed, protein concentration determined, and extracts stored at $-70^{\circ}$.

Horseradish peroxidase (HRP)-conjugated monoclonal antibody to $\mathrm{HbF}$ (Isolabs/Wallace) was used for ELISA determination of $\mathrm{HbF}$ concentration. Anti- $\mathrm{HbF}$ is approximately 100 times more reactive to $\mathrm{HbF}$ than $\mathrm{HbA}$. Standard curves were generated using $\mathrm{HbF}$ standard $(\sim 10 \% \mathrm{HbF}$, $90 \% \mathrm{HbA}$ ) serially diluted $1: 2$ in $25 \mu \mathrm{g} / \mathrm{mL}$ BSA from 1 to $0.015 \mu \mathrm{g} / \mathrm{mL}$ HbF. $25 \mu \mathrm{g} / \mathrm{mL}$ BSA served as the assay background control. Hypotonic lysates were diluted to $25 \mu \mathrm{g} / \mathrm{mL}$. Protein samples were added in triplicate to Immulon-4 microtiter plates for colorimetric detection or Microlite II microtiter plates for chemiluminescent 
detection (Dynex Technologies), using an excess of $0.1 \mathrm{M}$ $\mathrm{Na}_{2} \mathrm{HCO}_{3}$, pH 9.0, at room temperature for $2 \mathrm{hr}$. Plates were washed four times with $50 \mathrm{mM}$ Tris, $\mathrm{pH} 8.0,150 \mathrm{mM}$ $\mathrm{NaCl}$, and $0.05 \%$ Tween-20 (TST). Anti-HbF was diluted 1:1000 to 1:2000 in TST containing 1\% BSA (Fraction V) and $100 \mu \mathrm{L}$ was added to each well, incubated for $2 \mathrm{hr}$ at room temperature, washed four times with TST, and HRP substrate added. For colorimetric detection, $100 \mu \mathrm{L}$ of TMB substrate (Kirkegaard \& Perry Laboratories) was added and incubated for $30 \mathrm{~min}$, quenched by the addition of $20 \mu \mathrm{L} 4 \mathrm{~N} \mathrm{H}_{2} \mathrm{SO}_{4}$, and read at $450 \mathrm{~nm} / 630 \mathrm{~nm}$. For chemiluminescent detection, $100 \mu \mathrm{L}$ of complete LBA (Pierce Chemical Co) was added per well and measured $2 \mathrm{hr}$ post-substrate addition. Correlation coefficients of standard curves were $0.95-1.0$ and not accepted if below 0.9 .

\subsection{Human primary blood progenitor culture}

A two phase liquid culture system was used [33] with modification. Human blood partially enriched for mononuclear cells (buffy coat) was diluted 1:1 with sterile PBS laid over $1.077 \mathrm{~g} / \mathrm{mL}$ Ficoll (Invitrogen Corporation) and centrifuged at $\sim 300 \mathrm{~g}$. Mononuclear cells at the Ficollaqueous interface were removed, diluted with PBS, collected by centrifugation $(300 \mathrm{~g})$, and washed twice with PBS. Mononuclear cells containing erythroid progenitors from 2 units of blood were cultured in $80 \mathrm{~mL}$ 'Phase I' medium comprising: $\alpha$-modified Eagle's media ( $\alpha$ MEM; Invitrogen Corporation), 10\% FCS (Stem Cell Technologies), $20 \mathrm{mM}$ L-glutamine, penicillin (100 units $/ \mathrm{mL}$ ), streptomycin $(100 \mu \mathrm{g} / \mathrm{mL}$ ), human cytokines (R\&D Systems Inc.) $10 \mathrm{ng} / \mathrm{mL}$ IL-3, $10 \mathrm{ng} / \mathrm{mL}$ IL-6, $10 \mathrm{ng} / \mathrm{mL}$ granulocyte colony stimulating factor (G-CSF), $10 \mathrm{ng} / \mathrm{mL}$ granulocytemacrophage colony stimulating factor (GM-CSF), $20 \mathrm{ng} /$ $\mathrm{mL} \mathrm{SCF}$, and $1 \mu \mathrm{g} / \mathrm{mL}$ cyclosporin A (Cayman Chemical Corp.). Phase I culture was expanded for 5-7 days, collected by centrifugation, washed twice in $\alpha \mathrm{MEM}$, and transferred to 'Phase II' medium comprising: $\alpha \mathrm{MEM}, 10-30 \%$ FCS, $20 \mathrm{mM}$ L-glutamine, penicillin (100 units $/ \mathrm{mL})$, streptomycin $(100 \mu \mathrm{g} / \mathrm{mL}), 1$ unit/mL erythropoietin (EPO), $10 \mathrm{ng} /$ $\mathrm{mL}$ SCF, $1 \mu \mathrm{M}$ dexamethasone, $10 \mu \mathrm{M} \beta$-mercaptoethanol. The effect of compound on $\mathrm{HbF}$ in primary cultures was assessed by exposing cells plated in Phase II media at $3 \times 10^{6}$ cells $/ \mathrm{mL}, 5 \% \mathrm{CO}_{2}, 37^{\circ}$, in a humidified incubator, to a range of compound concentrations for 4 days (corresponding to days $4-8$ in Phase II).

\subsection{K562 extract preparation and protein blotting}

To measure histone acetylation, K562 cells $(1 \times$ $10^{7}$ cells) were exposed to compounds for $24 \mathrm{hr}$. Cells were pelleted by centrifugation $(500 \mathrm{~g} ; 5 \mathrm{~min})$, washed once with PBS followed by resuspension in $10 \mathrm{mM}$ HEPES, pH 7.9, $1.5 \mathrm{mM} \mathrm{MgCl}, 10 \mathrm{mM} \mathrm{KCl}, 0.5 \mathrm{mM}$ DTT, and $1.5 \mathrm{mM}$ PMSF. $\mathrm{HCl}$ was added to $0.2 \mathrm{M}$ for
$30 \mathrm{~min}$ at $4^{\circ}$. The extract was subjected to centrifugation at $11,000 \mathrm{~g}$, for $10 \mathrm{~min}$ at $4^{\circ}$. The supernatant fraction was dialyzed against $0.1 \mathrm{M}$ acetic acid (once for $1 \mathrm{hr}$ ), followed by dialysis against water (three times). Cell extracts were subjected to SDS-PAGE, transferred to nitrocellulose membrane, and incubated with anti-acetyl histone antibody (Upstate Biotechnology) for $2 \mathrm{hr}$ at room temperature. Primary antibody incubation was followed by incubation with the appropriate HRP-conjugated secondary antibody for $1 \mathrm{hr}$ at room temperature and chemiluminescent detection (ECL; Amersham Bioscience).

\subsection{Stress gene profiling}

HepG2 cells were stably transfected with individual reporter gene constructs employing the luciferase gene under the control of the stress-responsive promoters for c-jun, growth arrest and DNA damage 153 (GADD153), glutathione- $S$-transferase Ya (GST Ya), heme mono-oxygenase (HMO), heat shock protein 70 (HSP70), or the hypoxia inducible factor 1 (HIF-1 RE), nuclear factor AT (NF-AT RE), nuclear factor kappa-B (NF-кB RE), or xenobiotic (XRE) response elements. Stably transfected clonal cell lines were isolated and selected for appropriate response to two or more known modulators of the particular promoter element. Assay conditions for each cell line were optimized for exposure time, serum concentration, and cell number.

Cells were plated onto white 96-well microtiter plates precoated with collagen at either 10,000 (GADD153, HIF$1 \mathrm{RE}$ ) or 20,000 cells per well (c-jun, GST Ya, HSP70, HMO, NF-AT RE, NF-אB RE, XRE) in 150 mL DMEM supplemented with L-glutamine, non-essential amino acids, and either 1\% (GADD153, GST Ya, HIF-1 RE, HMO, NF-AT RE, NF- $\kappa \mathrm{B}$ RE, XRE) or $10 \%$ (c-jun, HSP70) FCS. After $24 \mathrm{hr}$ incubation $\left(37^{\circ}, 5 \% \mathrm{CO}_{2}\right)$ the cells were transferred to a fully robotic liquid and plate handling station where compounds were added in triplicate at six concentrations in a 5 -fold dilution range. The plates were further incubated for either $6 \mathrm{hr}$ (HMO), $8 \mathrm{hr}$ (c-jun, GADD153, GST Ya, NF-AT RE, NF-кB RE), $16 \mathrm{hr}$ (HSP70, XRE), or $24 \mathrm{hr}$ (GST Ya, assayed at two different time points), and luciferase assays performed.

\section{Results}

\subsection{Identification of compounds which increase $\gamma$-globin transcription in K562 and primary progenitor cells}

Our initial goal was to identify novel agents which induce $\gamma$-globin transcription through random HTS of $>186,000$ entities and to categorize their mechanisms of action. Two assay approaches were used: (1) a fusion of the LCR hypersensitivity site 2 enhancer with the $\gamma$ proximal promoter (HS2 $\gamma$ ) $5^{\prime}$ to a luciferase reporter gene (Fig. 1A); 


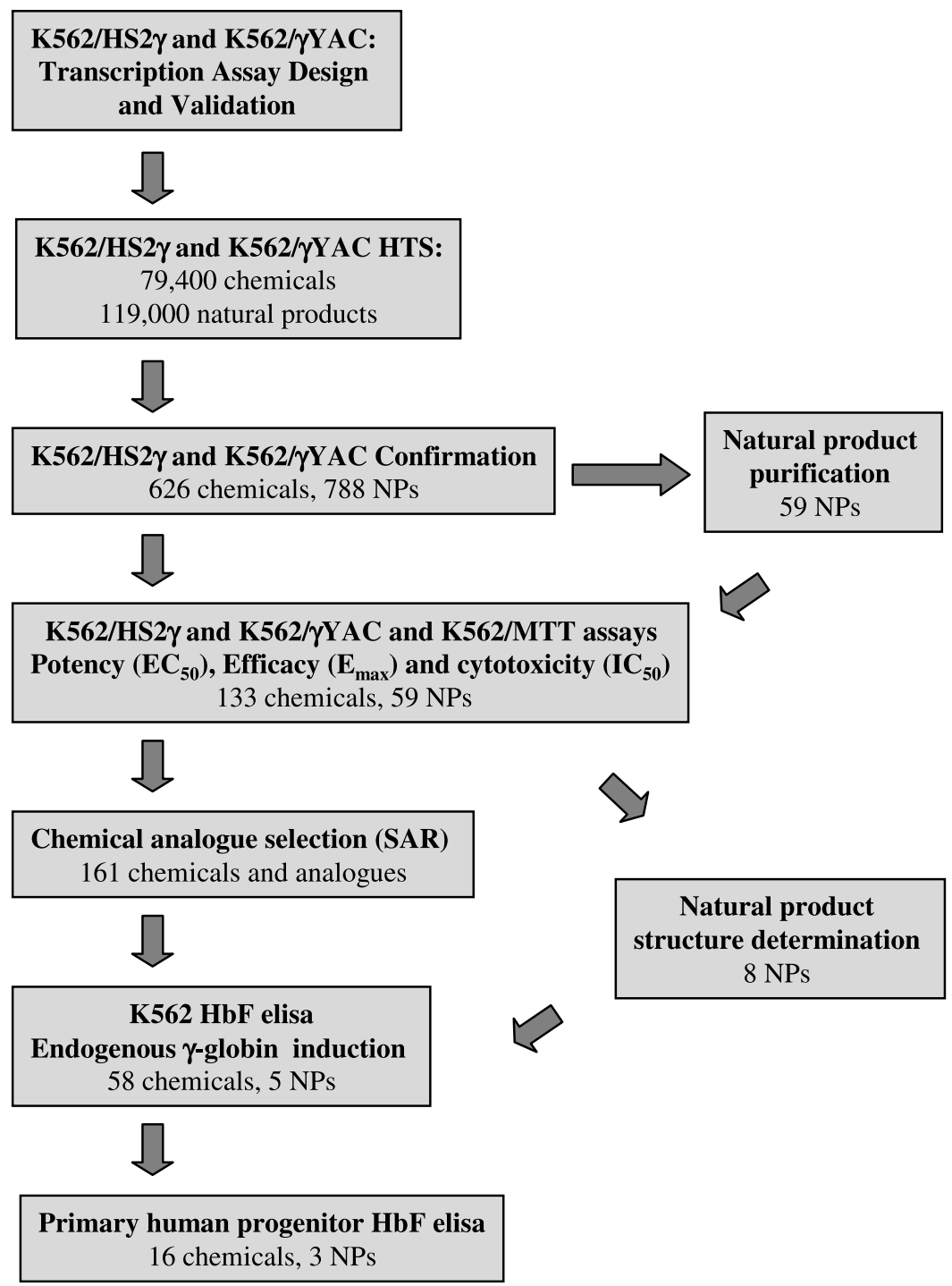

Fig. 2. Flow schematic illustrating natural product extract and chemical compound progression pathways.

and (2) a $\beta$ YAC-based approach in which the luciferase reporter gene was integrated by homologous recombination $3^{\prime}$ of the $\gamma$-globin promoter within the context of the full $\beta$-globin locus (Fig. 1B; ref. [32]). Extracts and compounds were evaluated and selected according to the scheme shown in Fig. 2, where inductions of $>4$-fold for HS $2 \gamma$ and of $>2$-fold for $\gamma$ YAC were required for further investigation of the test agent. Approximately 96,000 extracts from fungal, marine, seed, and herbal libraries and 48,400 compounds from chemical libraries were screened in the K562/ $\gamma \mathrm{YAC}$ assay and approximately 23,000 extracts and 31,000 compounds were screened in the K562/HS2 $\gamma$ assay. Extracts or compounds which increased $\gamma$-globin reporter activity greater than 4-fold in $\mathrm{K} 562 / \mathrm{HS} 2 \gamma$ cells or 2 -fold in $\mathrm{K} 562 / \gamma \mathrm{YAC}$ cells, as compared with vehicle control (0.2\% DMSO), were selected for further evaluation. The frequency distribution of the fold transcription increases from resulting incubation with chemical compound or fungal extracts are shown in Fig. 3. The $y$-axis records fold induction relative to control. Compounds or extracts are distributed along the $x$-axis, which has no units. Most extracts and compounds had little or no effect on $\gamma$-globin gene expression and showed a normal distribution centering on 1.0, or no fold induction. The scales between panels differ due to the increased sensitivity of HS2 $\gamma$ over $\gamma$ YAC and the often larger fold inductions observed with fungal extract mixtures relative to single chemical compounds. The enhanced activity of fungal extracts is most likely due to the sensitivity of the assay to specific classes of cytotoxic compounds and to the multiplex nature of whole fungal extracts (data not shown). The frequencies of identifying positively scoring compounds and natural product extracts in the automated screening approach were 1 and $2.5 \%$, respectively.

Active fungal culture extracts were prioritized on the basis of efficacy, potency, and cytotoxicity at 24 and $48 \mathrm{hr}$ time points. Extracts were dereplicated on the basis of HPLC retention time to eliminate previously identified 


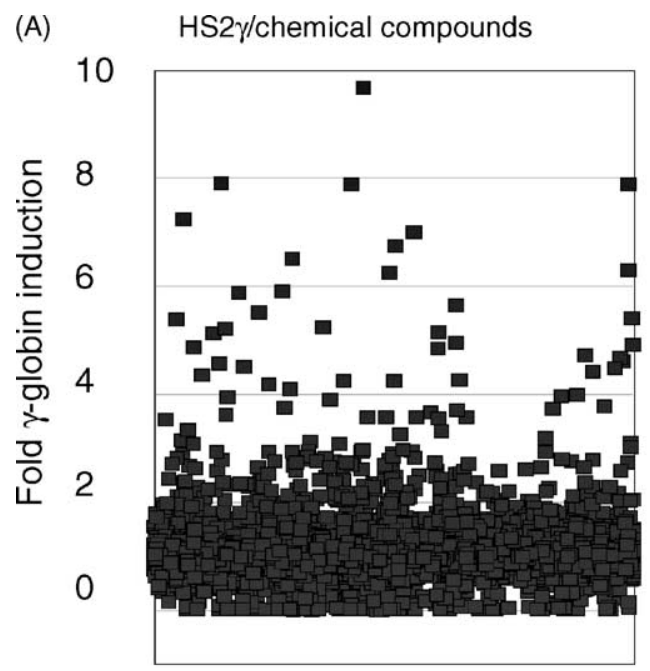

(C)

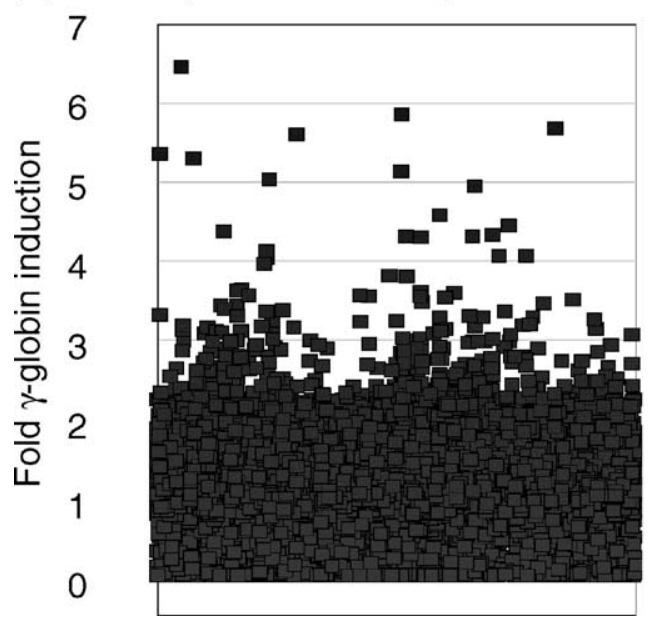

(B)

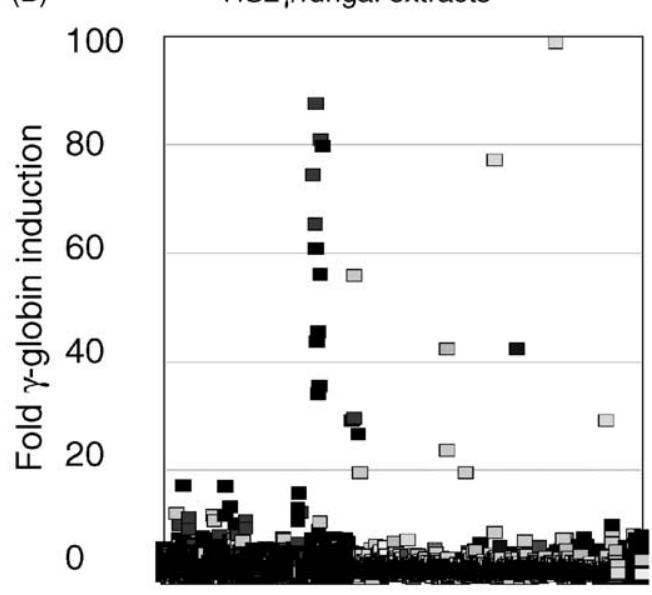

(D)

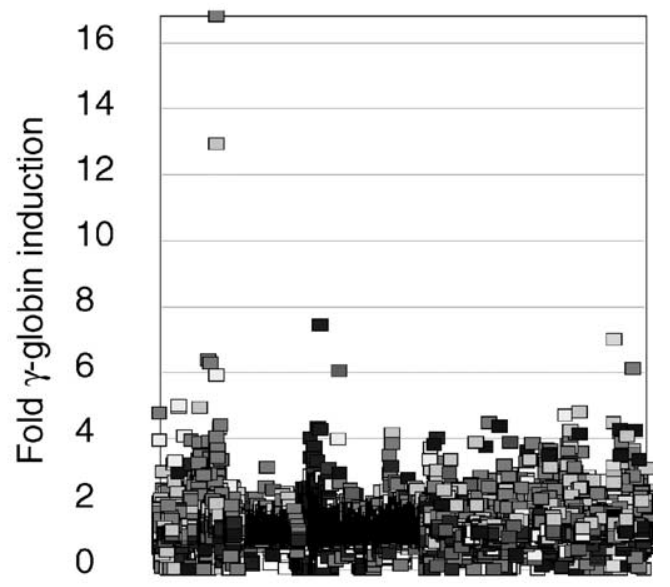

Fig. 3. Frequency distribution of fold transcription increases resulting incubation with chemical compounds or fungal extracts. The $y$-axis records fold induction relative to vehicle control (0.2\% DMSO). Compounds/extracts are distributed along the $x$-axis, which has no units. (A) HS2 $\gamma$ cells exposed to compounds (scale 0-10); (B) HS2 $\gamma$ cells exposed to fungal extracts (scale 0-100); (C) $\gamma$ YAC cells exposed to compounds (scale 0-7); and (D) $\gamma$ YAC cells exposed to fungal extracts (scale 0-17). Fold induction of 1 indicates no effect, while inductions $<1$ indicate cytotoxicity and/or repression. Clusters reflect related compounds in close proximity within the chemical and fungal extract libraries. Shading in panels B and D reflect different fungal growth conditions.

activities. From the 59 purified fungal metabolites, 5 potent and efficacious activities were characterized (not shown). These comprised a furanone (5-[1,2-dimethyl-propenyl]5-hydroxy-4-methoxy-5H-furan-2-one), an isoflavone (7-hydroxy-3-[4-hydroxy-phenyl]-chromen-4-one), a substituted phenol (1-[2,4,6-trimethoxy-phenyl]-but-2-en-1one), a dihydropyranone (acetic acid 2-[8-methyl-9-oxabicyclo[4.2.1]nona-2,4-dien-7yl]-6-oxo-3,6-dihydro- $2 \mathrm{H}$ pyran-3-yl-ester), and a cyclic tetrapeptide (OSI-2040; cyclo-[ $\mathrm{N}$ - $\mathrm{O}$-methyl-L-Trp-L-Ile-D-Pip-L-2-amino-8-oxodecanoyl]). Of the fungal metabolites, only OSI-2040 showed sufficient efficacy, potency, and differential cytotoxicity to warrant further study. OSI-2040, a cyclic tetrapeptide, was isolated from Fusaria extracts and likely is to be produced from tryptophan, isoleucine, a pipecolic acid, and an amino decane derivative. Three of the four residues are uncommon amino acids and active variants of OSI-2040 in which the nitrogen methoxy group is substituted with hydrogen also have been isolated. OSI-2040 refers to either methoxy or hydrogen substituted entity, which display indistinguishable bioactivity. OSI-2040 was shown to increase both $\gamma$-globin transcription [34] and HbF accumulation using three distinct assays: the HbF ELISA (Table 1), hemoglobin staining assays (benzidine colorimetric and LBA chemiluminescent assays; data not shown), and a hemoglobin cation-exchange HPLC assay (data not shown).

Of the chemical compounds, 62 were selected based on potency, efficacy, and relative lack of cytotoxicity. Of these, 35 were aniline derivatives. More than 20 of the anilines are condensed as either amides, ureas, or carboxamides. Activity profiles of selected compounds from each of the chemical classes are shown in Table 1. The anilide OSI-168961, the amide OSI-102695, and the benzoyl OSI169055 showed maximal transcriptional inductions of 3.2-, 
Table 1

Compound classes and activity in K562/ $\gamma$ YAC transcription assays, K562 cytotoxicity assay (MTT), K562 HbF ELISA, and human primary progenitor HbF ELISA

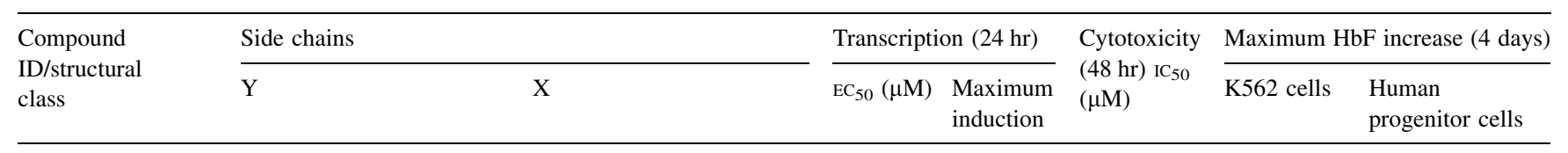

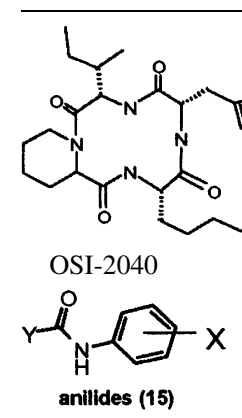

$\begin{array}{lll}\text { OSI-168961 } & \text { 1-Hydroxy 2-napthyl } & \text { 2-Chloro-4-nitro } \\ \text { OSI-168996 } & \begin{array}{l}\text { 1-Hydroxy-4-chloro } \\ \text { 2-napthyl }\end{array} & \text { 4-Cyano } \\ \text { OSI-97345 } & \text { 3-Methylbenzo[b]thiophene } & \text { 4-Methyl }\end{array}$<smiles>[X]C(=O)Nc1ccc([X])cc1</smiles>

\section{arbamates (6)}

OSI-168992

Cyclohexyl

2-Nitro
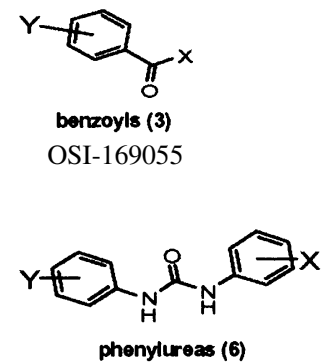

OSI-101820

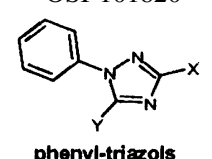

\section{phenyl-triazols}

OSI-169170

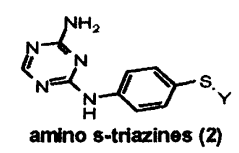

OSI-22121

2,3-Propylene

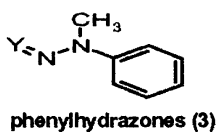

OSI-169040 3(2-Keto indolyl)<smiles>NC(=O)c1ccc(OCc2ccccc2Cl)nc1</smiles>

OSI-102695

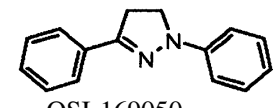

OSI-169050

Aza-cytidine

Hydroxyurea

Hydroxy
1-Benzyl-1Hpyrrolo(1,2-A)imidazol-5-yl $<0$ 8.0 3-Nitro

4-Methoxyphenyl

$\begin{array}{ll}0.1 & 3.2 \\ 1.0 & 3.8 \\ & \\ 5.0 & 3.6\end{array}$

$$
>50
$$$$
30
$$$$
>50
$$

$1.0 \quad 2.0$

$>20$

$3.1(20 \mu \mathrm{M}) \quad 2.6(0.8 \mu \mathrm{M})$
$2.8(2 \mu \mathrm{M}) \quad 2.4(0.8 \mu \mathrm{M})$ $3.8(0.7 \mu \mathrm{M}) \quad 2.4(0.8 \mu \mathrm{M})$

$2.0(15 \mu \mathrm{M}) \quad 4.1(4 \mu \mathrm{M})$

5.8

$>50$

$3.2(2 \mu \mathrm{M}) \quad 7.2(20 \mu \mathrm{M})$

$3.5 \quad 2.6$

30

$5.4(25 \mu \mathrm{M}) \quad 2.1(0.8 \mu \mathrm{M})$

9.0

2.9

$>50$

$2.0(20 \mu \mathrm{M}) \quad \mathrm{nd}$

0.9

2.5

$>20$

$1.7(20 \mu \mathrm{M}) \quad 3.5(4 \mu \mathrm{M})$

$\begin{array}{ll}0.4 & 3.0\end{array}$

$\begin{array}{ll}0.6 & 2.5\end{array}$

na

1.2

$2.3(6 \mu \mathrm{M}) \quad 1.5(20 \mu \mathrm{M})$

$3.1(1 \mu \mathrm{M}) \quad 10(1 \mu \mathrm{M})$ $2.8(200 \mu \mathrm{M}) 5.9(100 \mu \mathrm{M})$ 
2.5-, and 2.2-fold, respectively, potencies in the $\mathrm{nM} \mathrm{EC}_{50}$ range with cytotoxicity apparent at $>20 \mu \mathrm{M}$. The carbamate OSI-168992, and anilides OSI-97345 and OSI168996, the phenylurea OSI-101820, the phenyltriazol OSI-169170, the amino-triazine OSI-22121, and the phenylhydrazone OSI-169040 exhibited maximal inductions ranging from 2- to 5.8-fold with low $\mu \mathrm{M}$ potencies. In these assays, OSI-2040 showed a 4.3-fold stimulation of $\gamma$ YAC reporter activity after $24 \mathrm{hr}$ exposure with an $\mathrm{EC}_{50}$ of $\sim 150 \mathrm{nM}$ and cytotoxicity, following $48 \mathrm{hr}$ exposure in K562 cells in vitro, was apparent at concentrations $>500 \mathrm{nM}$. In comparison, aza-cytidine showed transcriptional activity $(\gamma$ YAC) of 2.5 -fold at $600 \mathrm{nM}$ with cytotoxicity apparent at $\sim 1 \mu \mathrm{M}$. The reference compounds sodium butyrate and hydroxyurea showed little or no induction $(<2$-fold) of reporter expression after $24 \mathrm{hr}$ exposure, but did increase reporter expression and $\mathrm{HbF}$ accumulation after longer incubation periods. For example, both hydroxyurea $(100 \mu \mathrm{M})$ and sodium butyrate $(1 \mathrm{mM})$ increased $\mathrm{K} 562 / \mathrm{HS} 2 \gamma$ expression by 10 -fold after $96 \mathrm{hr}$ exposure, while in the same experiment OSI-2040 $(0.3 \mu \mathrm{M})$ showed a 47 -fold increase. The assays for globin protein, the $\mathrm{HbF}$ ELISA, and the benzidine staining assay, generally were less sensitive. In K562 cells exposed to compounds for $72 \mathrm{hr}$ benzidine staining (measuring total globin protein) increased 8-fold for OSI-2040 $(4.8 \mu \mathrm{M})$, 2.5 -fold for hydroxyurea $(200 \mu \mathrm{M}), 3$-fold for hydroxyurea $(500 \mu \mathrm{M}), \sim 1.5$-fold for sodium butyrate $(1 \mathrm{mM})$, and 2.2fold for sodium butyrate $(5 \mathrm{mM})$. In the HbF ELISA measurements in K562 cell exposed to compound for $96 \mathrm{hr}$, hydroxyurea $(200 \mu \mathrm{M})$, aza-cytidine $(1 \mu \mathrm{M})$, and OSI-2040 (100 nM) increased HbF 2.8-, 3.1-, and 5.4-fold, respectively, as shown in Table 1 . Sodium butyrate was not tested in the HbF ELISA. These findings were generally true for many compounds where, at non-cytotoxic concentrations, $\mathrm{EC}_{50}$ values for potency increased with increased cell exposure time.

The selected compounds showed $\gamma$-globin-inducing activity in both K562 and primary human progenitor cells in vitro. Primary peripheral hematopoietic progenitor cells were cultured [33] under conditions resulting in the expansion and differentiation of erythroid cells and the induction of $\gamma$-globin (approximately days 2-4) and $\beta$-globin (approximately days 4-8). To minimize donor to donor variation progenitor cells from two to three donors were pooled in Phase II culture (day 4) and $\mathrm{HbF}$ concentration measured by ELISA. A relatively short incubation period of $96 \mathrm{hr}$ was used to minimize potential in vitro. Seven independent experiments were performed using duplicate cultures for each compound and with three ELISA determinations for each data point. A three-way ANOVA of the data was performed (compound vs. concentration vs. experiment; Table 1). Compound potencies generally were in the low $\mu \mathrm{M} \mathrm{EC}_{50}$ range, with $\mathrm{HbF}$ increases of 2- to 7.2-fold over concentrations from 0.8 to $20 \mu \mathrm{M}$ observed. The exception was OSI-2040 which showed significant $(P<0.05) \gamma$-globin-inducing activity of 5.4- and 4.5-fold in K562 and human progenitor cells, respectively, at low $\mathrm{nM}$ concentration (100 nM for K562 cells and $40 \mathrm{nM}$ for human progenitor cells). In comparison, aza-cytidine at $1 \mu \mathrm{M}$ showed inductions of 3.1- and 10-fold in K562 and human progenitor cells, respectively. Hydroxyurea showed $\gamma$-globin-inducing activity of 2.8 and 5.9-fold in K562 and human progenitor cells, though with low potency $(>100 \mu \mathrm{M})$.

\subsection{Directed screening for inducers of $\gamma$-globin transcription}

In initial validation studies, approximately 80 compounds with known activities in cellular signaling were evaluated in the K562/ $\gamma$ YAC assay. The compounds acetohydroxamic acid (urease inhibitor), genistein, and quercetin (tyrosine kinase inhibitor), 12-phorbol 13-myristate (protein kinase $\mathrm{C}$ activator), ionomycin, and A23187 (calcium influx), $N$-acetyl cysteine (antioxidant), phenamil (sodium channel blocker), and olomucine (cyclin-dependent kinase inhibitor) induced $\gamma$-globin promoter-reporter activity by $>2$-fold. Few of these compounds had sufficient potency $(<10 \mu \mathrm{M})$ or tractable chemical structures for further evaluation. However, analogs of acetohydroxamic acid were further investigated.

Proprionic hydroxamic acid (PHA) increased reporter activity in K562/HS $2 \gamma$ at concentrations $>4 \mu \mathrm{M}$, with maximal activity observed at $\sim 70 \mu \mathrm{M}$ as shown in Fig. 4 . Figure 4 shows $\log$ concentration in $\mu \mathrm{M}$ on the $x$-axis and fold increase in $\gamma$ expression on the $y$-axis. Increases in $\gamma$ transcription were time dependent, ranging from 2.6-fold at $48 \mathrm{hr}$ to 6.7 -fold at $120 \mathrm{hr}$ of exposure to $100 \mu \mathrm{M}$ PHA. Reducing PHA concentration to $20 \mu \mathrm{M}$ diminished $\gamma$ transcription to 2.1 - to 3.3 -fold at 48 and $120 \mathrm{hr}$ exposure, respectively. Six hydroxamic acid analogs were compared in order to assess possible structure-activity relationships. All analogs, with the exception of compound 15260 , were found to increase HS2 $\gamma$ expression (Table 2). R-02210 showed markedly greater induction at early time points than PHA, NS43789, or R-44534, despite showing similar maximal inductions of $\sim 5$ to 7-fold at or around $100 \mu \mathrm{M}$ compound concentration. Both R-02761 and NS41080 were more potent, with maximal activity observed at $\sim 20 \mu \mathrm{M}$. However, NS41080 showed less time dependence to HS2 $\gamma$ induction and showed a more pronounced leftward tail in the dose-response curves, suggestive of a greater window between the efficacious and cytotoxic compound concentrations.

\subsection{HDA inhibition and activation of cellular stress pathways}

Short chain fatty acids, such as butyrate, have been shown to induce $\gamma$-globin transcription and exhibit HDA 


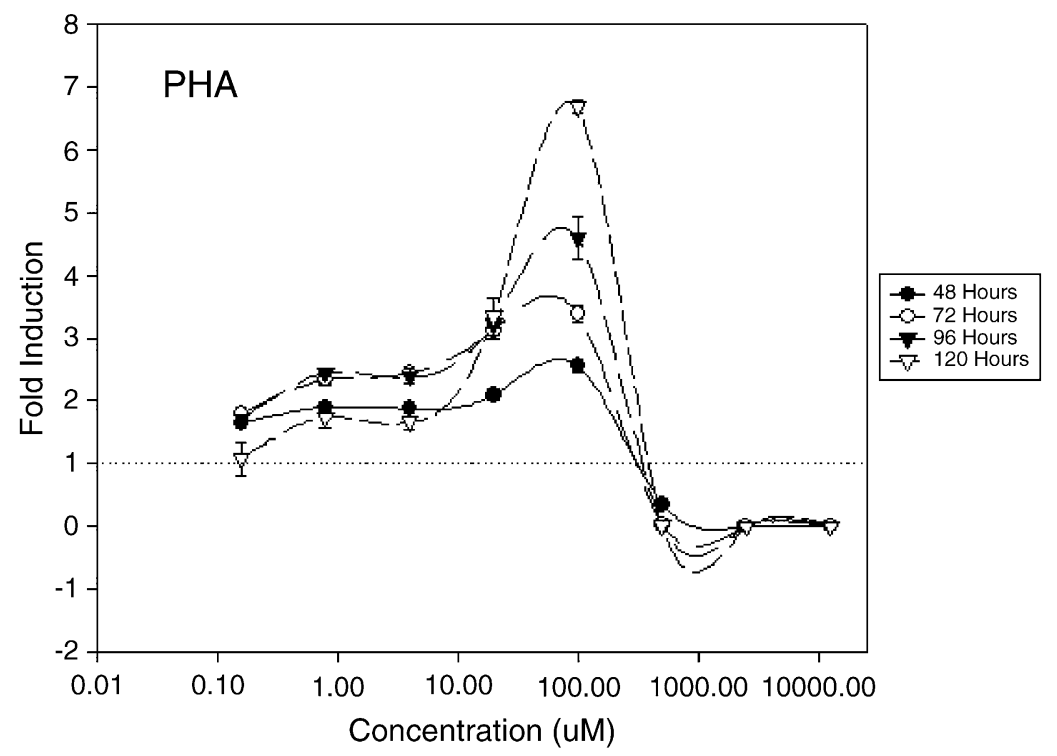

Fig. 4. Dose-response activity profile of K562/HS2 $\gamma$ cells exposed to proprionic hydroxamic acid (PHA) for 48, 72, 96, or 120 hr. Log concentration is indicated on the $x$-axis. Fold $\gamma$-globin transcriptional increase is shown on the $y$-axis.

inhibitory activity at relatively high concentrations [35]. The potential for the $\gamma$-globin-inducing compounds to inhibit HDA activity in K562 cells was examined. Using anti-acetyl histone antibody, increased acetylated histone was clearly observed in cells exposed to OSI-2040 for $18 \mathrm{hr}$, but was not detected in K562 cells treated with other $\gamma$-globin-inducing compounds (Fig. 5A). In separate experiments, PHA also was shown to have HDA inhibitory activity

Table 2

Activity of hydroxamate-containing analogs in stimulating $\gamma$-globin transcription after $96 \mathrm{hr}$ exposure in KS62/HS2 $\gamma$ cells

\begin{tabular}{|c|c|c|c|}
\hline Compound & Structure & $\mathrm{EC}_{50}(\mu \mathrm{M})$ & Maximal fold induction \\
\hline Acetohydroxamic acid & & 250 & 2.6 \\
\hline Proprionic hydroxamic acid & & 30 & 4.7 \\
\hline $\mathrm{R}-02210$ & & 50 & 5.5 \\
\hline R-02761 & & 4 & 3.0 \\
\hline R-44534 & & 50 & 4.1 \\
\hline 15260 & & - & No effect \\
\hline NS41080 & & 5 & 4.0 \\
\hline NS43789 & & 40 & 4.0 \\
\hline
\end{tabular}


in K562 cells (Fig. 5B). The OSI-2040 concentration used was $1 \mu \mathrm{M}$, which provides maximal $\gamma$-globin-inducing activity yet was below the $24 \mathrm{hr}$ cytotoxic $\mathrm{IC}_{50}$.

Many of the $\gamma$-globin-inducing compounds initially identified showed cytotoxicity, as measured by a reduction in MTT conversion and by a sharp decline in reporter signal, at concentrations at or somewhat above those required for maximal induction of transcription. To investigate whether stress-responsive pathways form an obligate mechanism in $\gamma$-globin induction, the active compounds

(A)

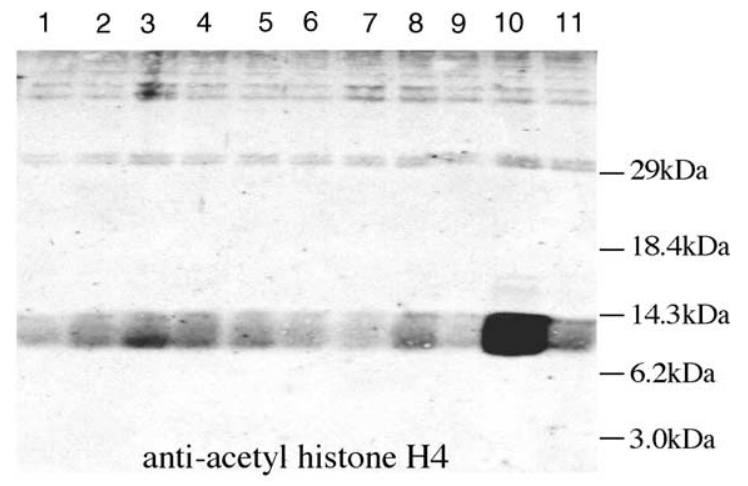

(B)

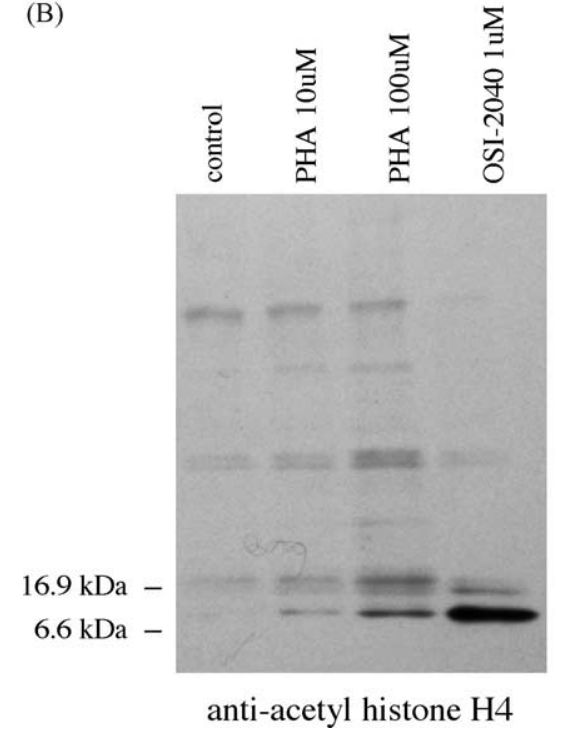

Fig. 5. (A) OSI-2040 treatment increases histone H4 acetylation in K562 cells. K562 cells were treated for $24 \mathrm{hr}$ with maximally acting concentration of OSI-97345 (lane 1), OSI-102695 (lane 2), OSI-22121 (lane 3), OSI-101820 (lane 4), OSI-168992 (lane 5), OSI-168996 (lane 6), OSI-168961 (lane 7), OSI-169050 (lane 8), OSI-169170 (lane 9), OSI2040 (lane 10), or $0.2 \%$ DMSO (lane 11). Extracts were subjected to SDSPAGE, transferred to nitrocellulose, and probed with anti-acetyl histone $\mathrm{H} 4$ antibody (Upstate Biotechnology). Acetyl histone H4 (11 kDa) was observed extracts from OSI-2040-treated cells, but not in extracts from cells exposed to $0.2 \%$ DMSO or compounds OSI-97345 to OSI-169170. Weak reactivity of the antibody to acetylated histone H2B (14 kDa) may contribute to band broadening. (B) Proprionic hydroxamic acid (PHA) stimulates histone $\mathrm{H} 4$ acetylation in K562 cells. K562 cells were treated for $24 \mathrm{hr}$ with $0.2 \%$ DMSO vehicle (lane 1), $10 \mu \mathrm{M}$ PHA (lane 2), $100 \mu \mathrm{M}$ PHA (lane 3), $1 \mu \mathrm{M}$ OSI-2040 (lane 4) histones extracted and probed with anti-acetyl histone antibody as described for panel A. The OSI-2040 concentration of $1 \mu \mathrm{M}$ provides maximal $\gamma$-globin-inducing activity yet was below the $24 \mathrm{hr}$ cytotoxic $\mathrm{IC}_{50}$.
OSI-97345, OSI-102695, OSI-101820, OSI-168996, OSI168961, OSI-169050, OSI-169170, OSI-2040, and 5-azacytidine were investigated for their ability to induce the stress-responsive promoters or response elements from c-jun (early-immediate stress response), GADD153 (growth arrest and DNA damage), GST Ya (Phase II metabolic enzyme), HIF-1 RE (hypoxia response element), HSP70 (heat shock and protein damage), heme oxygenase (oxidative stress), NF- $\mathrm{kB}$ RE (oxidative stress, DNA damage), NF-AT (calcium signaling), and XRE (aryl hydrocarbon (AH) receptor activation). A panel of nine stably transfected HepG2 cells containing luciferase reporter genes linked to individual promoters and response elements were exposed to each of the compounds along with an appropriate positive control for each marker, in triplicate at six doses (5-fold serial dilutions) as described in Section 2.

Table 3 indicates stress markers which were significantly induced by each compound ( $>2$-fold induction, $P=0.05$ ), the magnitude of the greatest observed induction (in fold induction and as a percentage of the maximum observed effect), the dose at which the highest induction was observed and the $P$ value obtained from a $t$-test of the triplicate dose points compared to the 12 negative controls in each case. Only treatments resulting in at least a 2-fold $(P<0.05)$ increase in luciferase expression are shown. Shown is the concentration of compound at which maximum induction of stress response was seen, fold increase in luciferase activity, \% of maximum observed increase, and $P$ value ( $t$-test). Notably, all of the compounds, with the exception of OSI-169170, induced transcription of the XRE reporter construct, suggesting that these compounds are able to bind and activate the AH receptor. OSI-97345 was the most powerful inducer of XRE, causing a 5-fold increase in luciferase expression at a dose of $16.7 \mu \mathrm{M}$. OSI2040 was the most potent inducer of XRE, giving a 4-fold increase at $0.12 \mu \mathrm{M}$. Four of the compounds, OSI-2040, OSI-97345, OSI-102695, and OSI-169170, induced expression from the HSP70 promoter. Increased expression of HSP70 would suggest that exposure of cells to these compounds results in damage to proteins or a disruption of protein synthesis or folding [36]. Induction of HSP70 driven luciferase expression by OSI-97345, OSI-102695, and OSI-169170 was fairly weak ( 2.5-fold) but OSI-2040 induced a 6.8 -fold increase in expression, comparable to that observed with the alkylating agent methane methyl sulfonate (MMS). OSI-2040 also induced the GADD153 reporter construct which may indicate a genotoxic potential [37], as well as the c-jun and NF- $\kappa \mathrm{B}$ RE constructs. The level of induction of GADD153 by OSI-2040 was small (2.1-fold) compared to that observed with MMS (15.2-fold) and the effect of OSI-2040 on the c-jun and NF-KB RE constructs was also small. OSI-169050 and OSI-169170 also weakly induced the GADD153 reporter construct (2.3- and 2.1-fold, respectively). Neither OSI169050 nor OSI-169170 significantly induced c-jun or NF- $\kappa B$ RE, although both did induce the GST Ya construct, 
Table 3

Maximum fold inductions of nine stress response reporter constructs by $\gamma$-globin transcription-inducing and control compounds

\begin{tabular}{|c|c|c|c|c|c|}
\hline Compound & [Compound] $(\mu \mathrm{M})$ & Markers induced $>2$-fold $(P \leq 0.05)$ & Fold induction & $\% \operatorname{Max}$ & $P$ \\
\hline \multicolumn{6}{|l|}{ Control compounds } \\
\hline \multirow[t]{4}{*}{ 3-Methyl cholanthrene } & 20 & GST Ya (8 hr) & 2.7 & 20 & 0.007 \\
\hline & 20 & GST Ya (24 hr) & 5.0 & 100 & 0.004 \\
\hline & 7 & HIF-1 RE & 3.7 & 100 & 0.006 \\
\hline & 20 & XRE & 5.5 & 48 & 0.001 \\
\hline \multirow[t]{2}{*}{ Calcium ionophore (A23187) } & 2 & HSP70 & 3.3 & 8 & 0.020 \\
\hline & 20 & NF-AT & 11.4 & 100 & 0.001 \\
\hline \multirow[t]{5}{*}{ Methane methyl sulfonate (MMS) } & 1000 & c-jun & 10.1 & 100 & 0.000 \\
\hline & 1000 & GADD153 & 15.2 & 58 & 0.000 \\
\hline & 333 & GST Ya $(8 \mathrm{hr})$ & 4.7 & 40 & 0.012 \\
\hline & 333 & HSP70 & 5.9 & 24 & 0.036 \\
\hline & 333 & $\mathrm{XRE}$ & 2.1 & 12 & 0.004 \\
\hline \multirow[t]{8}{*}{ 12-Phorbol 13-myristate (PMA) } & 0.7 & c-jun & 8.1 & 78 & 0.000 \\
\hline & 0.2 & GADD153 & 25.5 & 100 & 0.001 \\
\hline & 0.7 & GST Ya $(8 \mathrm{hr})$ & 10.2 & 100 & 0.001 \\
\hline & 0.2 & HMO & 19.8 & 100 & 0.001 \\
\hline & 0.2 & HSP70 & 21.7 & 100 & 0.004 \\
\hline & 0.7 & NF- $\kappa B$ RE & 1030.0 & 100 & 0.004 \\
\hline & 2 & NF-AT & 8.6 & 60 & 0.029 \\
\hline & 0.7 & XRE & 10.2 & 98 & 0.019 \\
\hline \multicolumn{6}{|l|}{ Test compounds } \\
\hline \multirow[t]{4}{*}{ OSI-97345 } & 17 & GST Ya (8 hr) & 2.5 & 16 & 0.005 \\
\hline & 17 & GST Ya $(24 \mathrm{hr})$ & 2.8 & 38 & 0.010 \\
\hline & 6 & HSP70 & 2.4 & 7 & 0.028 \\
\hline & 17 & XRE & 5.0 & 44 & 0.000 \\
\hline \multirow[t]{3}{*}{ OSI-102695 } & 4.2 & GST Ya (24 hr) & 2.0 & 18 & 0.043 \\
\hline & 1.4 & HSP70 & 2.1 & 4 & 0.043 \\
\hline & 13 & XRE & 2.5 & 16 & 0.003 \\
\hline OSI-101820 & 14 & XRE & 2.9 & 20 & 0.001 \\
\hline \multirow[t]{2}{*}{ OSI- 168992} & 1.9 & HIF-1 RE & 2.2 & 48 & 0.000 \\
\hline & 0.6 & XRE & 2.8 & 20 & 0.003 \\
\hline \multirow[t]{2}{*}{ OSI-168961 } & 8 & HIF-1 RE & 2.4 & 79 & 0.035 \\
\hline & 3 & XRE & 2.3 & 15 & 0.006 \\
\hline \multirow[t]{5}{*}{ OSI- 169050} & 14 & GADD153 & 2.3 & 6 & 0.004 \\
\hline & 42 & GST Ya (8 hr) & 2.3 & 13 & 0.009 \\
\hline & 125 & GST Ya (24 hr) & 2.5 & 27 & 0.003 \\
\hline & 42 & HIF-1 RE & 3.3 & 95 & 0.000 \\
\hline & 42 & XRE & 3.9 & 32 & 0.002 \\
\hline \multirow[t]{2}{*}{ OSI-169170 } & 42 & GADD153 & 2.1 & 5 & 0.001 \\
\hline & 14 & GST Ya $(8 \mathrm{hr})$ & 2.1 & 12 & 0.019 \\
\hline \multirow[t]{5}{*}{ OSI-2040 } & 10 & c-jun & 2.0 & 11 & 0.006 \\
\hline & 10 & GADD153 & 2.1 & 4 & 0.000 \\
\hline & 0.4 & HSP70 & 6.8 & 28 & 0.022 \\
\hline & 10 & NF- $\kappa B$ RE & 4.1 & 0 & 0.022 \\
\hline & 0.1 & XRB & 4.2 & 34 & 0.006 \\
\hline Proprionohydroxamic acid (PHA) & $<50$ & None & - & - & - \\
\hline
\end{tabular}

as did OSI-97345 and OSI-102695. Expression of GST Ya is induced in response to a variety of electrophilic compounds and phenolic antioxidants [38].

The HIF-1 RE construct was induced by the compounds OSI-168996, OSI-168961, and OSI-169050, suggesting that these compounds elicit a hypoxia response in HepG2 cells. Our own previous work with this cell line ${ }^{1}$ has shown that the HIF-1 RE reporter construct may be activated by compounds known to activate the $\mathrm{AH}$ receptor, such as 3-methylcholanthrene (MC) and benzo(a)pyrene (MC

\footnotetext{
${ }^{1}$ Unpublished results.
}

elicited a 3.7-fold increase in HIF-1 RE driven luciferase expression in this study). Not all of the compounds which induced the XRE construct also induced the HIF-1 RE construct, however, indicating that the responses are not completely equivalent.

\section{Discussion}

Chemically diverse compounds which induce $\gamma$-globin transcription through HDA inhibitory and distinct cell stress-associated mechanisms were identified. These effects 
could be observed in both K562 cells and human primary progenitor cells. In evaluating the screening systems employed, the isolated K562/HS2 $\gamma$ clones were considerably more responsive to the $\mathrm{K} 562 / \gamma \mathrm{YAC}$ clones to compounds which induce the transcription of $\gamma$-globin, for example, as observed in the frequency distribution data shown in Fig. 3. This was true both with known compounds, like aza-cytidine and hydroxyurea, and the novel compounds identified here. Both K562/HS2 $\gamma$ and K562/ $\gamma$ YAC reporter cell lines identified compounds capable of increasing $\gamma$-globin expression both in the reporter assays as well as in human primary progenitor cells (Table 1).

The majority of the compounds which activated $\gamma$-globin transcription shared a common motif of two aryl moieties separated by less than $4 \AA$ using one, two, and three bond linkers of several types (urea, carbamate, amide, carbonyl, ether, thiourea, etc.). The phenyl imidazoles, phenylhydrazones, and phenyltriazols also may fall into this general structural class. Whether these compounds interact with the same cellular targets as the related, less potent compound, hydroxyurea, or have distinct protein targets remains to be determined. The most potent and efficacious activity was observed with the HDA inhibitor OSI-2040, which markedly increased $\mathrm{HbF}$ both in established and primary erythroid cell cultures at low $\mathrm{nM}$ concentration. The HDA inhibitory activity of OSI-2040 (termed apicidin by Merck) has been reported by other investigators [39-41] and found to be more effective than trichostatin A and MS275 in stimulating histone hyperacetylation in K562 cells [39]. PHA also was shown to inhibit HDA, though with much lower potency and with slower kinetics of both HDA inhibition and $\gamma$-globin induction. Both aceto- and proprionic hydroxamic acids have been clinically investigated as urease inhibitors and showed good aqueous solubility. The hydroxamates generally showed relatively poor potency $(>20 \mu \mathrm{M})$ but exhibited substantial efficacy after long-term exposure $(96 \mathrm{hr}$ ) as shown for PHA in Fig. 4.

One central question we investigated here was whether compounds which induce $\gamma$-globin could be non-toxic at efficacious concentrations in vitro. The data obtained from screening of $>186,000$ compounds and extracts suggest that for the vast majority of compounds tested some degree of cytotoxicity is required for $\gamma$-globin induction. One of the better tolerated cytotoxic chemotherapy agents which can increase $\mathrm{HbF}$ is hydroxyurea, sometimes used clinically in combination with EPO [28]. It has been proposed that hydroxyurea acts to stimulate the synthesis of early erythroid progenitors capable of $\gamma$-globin transcription, presumably through preferential ablation of a more mature cell compartment leading to progenitor cell expansion. Recent data have shown hydroxyurea can activate p38 MAP kinase in a sustained fashion and attenuated extracellular signal-related kinase (ERK) and the c-jun $\mathrm{N}$ terminal kinase (JNK). Further, inhibition of p38 reduced the ability of hydroxyurea to stimulate globin production in K562 cells [42], strengthening a role for p38 activation in hydroxyurea action. In the case of the biaryl substituted ureas, amides, and carbamates, the common mechanistic response was the activation of the aryl hydrocarbon response pathway (XRE) and not the activation of c-jun. The mechanisms of these compounds were distinct from those of OSI-2040 which has potent HDA inhibitory activity and a distinct gene expression pattern as measured by microarray hybridization and by RT-PCR. ${ }^{2}$ Alterations in cell cycling have been inversely correlated with transcription of $\gamma$-globin [43]. One frequently used measure of cell cycling is the phosphorylation status of the retinoblastoma protein $(\mathrm{Rb})$, which is phosphorylated in the $\mathrm{G}_{1}$ to $S$ transition. In T47D cells, many of the $\gamma$-globininducing compounds identified here cause the hypophosphorylation of $\mathrm{Rb}$, indicative of cell cycle arrest or delay (data not shown). Conversely, in preliminary experiments the cdk inhibitors, roscovitine and olomucine, increased the expression of the $\gamma$-globin reporter line K562/HS2 $\gamma$ (data not shown), though their inductions were modest compared to the HDA inhibitor OSI-2040. These data support the hypothesis that the biaryl ureas, amides, and carbamates, act in part through cell cycle-dependent mechanisms, though the precise mechanisms by which these compounds act to alter the process of erythroid maturation and $\mathrm{F}$ cell production remain a point of continued investigation. It should be stressed that not all cytotoxic chemotherapeutic agents can induce the synthesis of $\mathrm{HbF}$, indicating some degree of specificity in the signaling pathway requirements for $\gamma$-globin induction. Further, while cell cycle delay can contribute to induction of $\gamma$-globin transcription, other events, for example, alterations in chromatin structure, are likely required for full activation of $\gamma$ gene expression. Even in the compounds identified here, which were selected for a relative lack of in vitro toxicity, a significant $(P<0.01)$ trend between maximal $\gamma$ induction and onset of cytotoxicity can be observed. The apparent outlier, PHA, may be explained by the relatively long period of time $(\sim 96 \mathrm{hr})$ required for maximal $\gamma$ transcription and the shorter time periods used for stress gene measurement $(<25 \mathrm{hr})$. An onset of cytotoxicity was frequently observed at concentrations close or at that required for maximal $\gamma$-globin induction, producing steep, bell-shaped dose-response curves (e.g. Fig. 4), strongly suggesting cell stress mechanisms form an obligate part of $\gamma$-globin-inducing action.

Here, we have developed screening methods useful in identifying compounds which stimulate $\gamma$-globin transcription and promote $\mathrm{HbF}$ production. The novel chemical compounds identified here provide pharmacophores for the development of new $\mathrm{HbF}$ elevating compounds for treatment of sickle disease and possibly Cooley's anemia. They further provide tools by which the multiple mechanisms of pharmacological up-regulation of $\gamma$-globin transcription may be investigated.

\footnotetext{
${ }^{2}$ J.D.H., unpublished results.
} 


\section{Acknowledgments}

We thank David Houck, Ping Cai, John Slack, Paul Ney, George Dover, and Arthur Nienhuis for materials and helpful advice. A portion of this work was funded under support from the National Heart, Lung and Blood Institute, NIH (R44 HL50935 and R01 HL57595) to J.D.H.

\section{References}

[1] Noguchi CT, Haley JD, Abraham DJ, Schechter AN. Inhibition of sickle hemoglobin polymerization as a basis for therapeutic approaches to sickle cell anemia. In: Abraham DJ, editor. Burger's medicinal chemistry and drug discovery. 6th ed., vol. 3. New York: Wiley; 2003.

[2] Clegg JB, Weatherall DJ. Thalassemia and malaria: new insights into an old problem. Proc Assoc Am Physicians 1999;111:278-82.

[3] Stamatoyannopoulos G, Nienhuis AW. Hemoglobin switching. In: Stamatoyannopoulos G, Nienhuis AW, Majerus P, Varmus H, editors. The molecular basis of blood diseases. Philadelphia: WB Saunders; 1994. p. 107-55.

[4] Berg P, Schechter A. The impact of molecular biology on the diagnosis and treatment of hemoglobin disorders. Mol Genet Med 1992;2:1-38.

[5] Chada K, Magram J, Constantini F. An embryonic pattern of expression of a human fetal globin gene in transgenic mice. Nature 1986;319: 685-9.

[6] Chada K, Magram J, Raphael K, Radice G, Lacy E, Constantini F. Specific expression of a foreign beta-globin gene in erythroid cells of transgenic mice. Nature 1985;314:377-80.

[7] Kollias G, Wrighton N, Hurst J, Grosveld F. Regulated expression of human A gamma-, beta-, and hybrid gamma beta-globin genes in transgenic mice: manipulation of the developmental expression patterns. Cell 1986;46:89-94.

[8] Rutherford T, Nienhuis AW. Human globin gene promoter sequences are sufficient for specific expression of a hybrid gene transfected into tissue culture cells. Mol Cell Biol 1987;7:398-402.

[9] Tuan D, Solomon W, Li Q, London IM. The "beta-like-globin" gene domain in human erythroid cells. Proc Natl Acad Sci USA 1985;82: 6384-8.

[10] Grosveld F, van Assendelft GB, Greaves DR, Kollias G. Positionindependent, high-level expression of the human beta-globin gene in transgenic mice. Cell 1987;51:975-85.

[11] Talbot D, Collis P, Antoniou M, Vidal M, Grosveld F, Greaves DR. A dominant control region from the human beta-globin locus conferring integration site-independent gene expression. Nature 1989; 338:352-5.

[12] Wijgerde M, Grosveld F, Fraser P. Transcription complex stability and chromatin dynamics in vivo. Nature 1995;377:209-13.

[13] Wood WG. The complexities of beta globin gene regulation. Trends Genet 1996;12:204-6.

[14] Poillon WN, Kim B, Rodgers G, Noguchi C, Schechter A. Sparing effect of hemoglobin $\mathrm{F}$ and hemoglobin $\mathrm{A} 2$ on the polymerization of hemoglobin $\mathrm{S}$ at physiologic ligand saturations. Proc Natl Acad Sci USA 1993;90:5039-43.

[15] Atweh GF, Sutton M, Nassif I, Boosalis V, Dover GJ, Wallenstein S, Wright E, McMahon L, Stamatoyannopoulos G, Faller DV, Perrine SP. Sustained induction of fetal hemoglobin by pulse butyrate therapy in sickle cell disease. Blood 1999;93:1790-7.

[16] Noguchi CT, Rodgers G, Serjeant G, Schechter AN. Levels of fetal hemoglobin necessary for treatment of sickle cell disease. New Engl J Med 1988;318:96-9.

[17] Zhou W, Clouston DR, Wang X, Cerruti L, Cunningham JM, Jane SM. Induction of human fetal globin gene expression by a novel erythroid factor, NF-E4. Mol Cell Biol 2000;20:7662-72.
[18] Asano H, Li X, Stamatoyannopoulos G. FKLF a novel Kruppel-like factor that activates human embryonic and fetal beta-like globin genes. Mol Cell Biol 1999;19:3571-9.

[19] Asano H, Li X, Stamatoyannopoulos G. FKLF-2: a novel Kruppel-like transcriptional factor that activates globin and other erythroid lineage genes. Blood 2000;95:3578-84.

[20] Jane SM, Nienhuis AW, Cunningham JM. Hemoglobin switching in man and chicken is mediated by a heteromeric complex between the ubiquitous transcription factor CP2 and a developmentally specific protein. EMBO J 1995;14:97-105.

[21] Yang Z, Engel JD. Biochemical characterization of the developmental stage- and tissue-specific erythroid transcription factor, NF-E4. J Biol Chem 1994;269:10079-87.

[22] Gumucio DL, Rood KL, Gray TA, Riordan MF, Sartor CI, Collins FS. Nuclear proteins that bind the human gamma-globin gene promoter: alterations in binding produced by point mutations associated with hereditary persistence of fetal hemoglobin. Mol Cell Biol 1988;8: 5310-22.

[23] Gumucio DL, Shelton DA, Zhu W, Millinoff D, Gray T, Bock JH, Slightom JL, Goodman M. Evolutionary strategies for the elucidation of cis and trans factors that regulate the developmental switching programs of the beta-like globin genes. Mol Phylogenet Evol 1996;5:18-32.

[24] McDonagh KT, Lin HJ, Lowrey CH, Bodine DM, Nienhuis AW. The upstream region of the human gamma-globin gene promoter. Identification and functional analysis of nuclear protein binding sites. J Biol Chem 1991;266:11965-74.

[25] Turner J, Crossley M. Basic Kruppel-like factor functions within a network of interacting haematopoietic transcription factors. Int $\mathrm{J}$ Biochem Cell Biol 1999;31:1169-74.

[26] DeSimone J, Heller P, Hall I, Zwiers D. 5-Azacytidine stimulates fetal hemoglobin synthesis in anemic baboons. Proc Natl Acad Sci USA 1982;79:4428-31.

[27] Koshy M, Dorn L, Bressler L, Molokie R, Lavelle D, Talischy N, Hoffman R, van Overveld W, DeSimone J. 2-Deoxy-5-azacytidine and fetal hemoglobin induction in sickle cell anemia. Blood 2000;96: 2379-84.

[28] Charache S, Terrin ML, Moore RD, Dover GJ, Barton FB, Eckert SV, McMahon RP, Bonds DR. Effect of hydroxyurea on the frequency of painful crises in sickle cell anemia. New Engl J Med 1995;332:1317-22.

[29] Pace BS, White GL, Dover GJ, Boosalis MS, Faller DV, Perrine SP. Short-chain fatty acid derivatives induce fetal globin expression and erythropoiesis in vivo. Blood 2002;100:4640-8.

[30] Ney P, Sorrentino B, Lowrey C, Nienhuis AW. Inducibility of the HS II enhancer depends on binding of an erythroid specific nuclear protein. Nucleic Acid Res 1990;18:6011-7.

[31] de Wet JR, Wood K, DeLuca M, Helinski D, Subramani S. Firefly luciferase gene: structure and expression in mammalian cells. Mol Cell Biol 1987;7:725-37.

[32] Grosveld F, Antoniou M, Berry M, deBoer E, Dillon N, Drabek D, Ellis J, Fraser P, Haley J, Philipsen S, Pruzina S, Raguz-Bolognesi S, Smith D, Trimbon T, Wijgerde M. Drug discovery and the transcriptional control of the human beta globin locus. In: Browne MJ, Thurlby PL, editors. Genomes, molecular biology and drug discovery. New York: Academic Press; 1996. p. 117-27.

[33] Fibach E, Burke LP, Schechter A, Noguchi C, Rodgers G. Hydroxyurea increases fetal hemoglobin in cultured erythroid cells derived from normal individuals and patients with sickle cell anemia or betathalassemia. Blood 1993;81:1630-5.

[34] Holmes M, Haley JD, Cerruti L, Zhou WL, Zogos H, Smith D, Cunningham JM, Jane SM. Identification of Id2 as a globin regulatory protein by representational difference analysis of K562 cells induced to express gamma globin with a novel fungal compound. Mol Cell Biol 1999;19:4182-90.

[35] Riggs M, Whittaker R, Neumann J, Ingram V. $n$-Butyrate causes histone modification in HeLa and Friend erythroleukaemia cells. Nature 1977;268:462-4. 
[36] Mosser DD, Theodorakis NG, Morimoto RI. Coordinate changes in heat shock element-binding activity and HSP70 gene transcription rates in human cells. Mol Cell Biol 1988;8:4736-44.

[37] Luethy JD, Holbrook NJ. Activation of the gadd 153 promoter by genotoxic agents: a rapid and specific response to DNA damage. Cancer Res 1992;52:5-10.

[38] Prestera T, Talalay P. Electrophile and antioxidant regulation of enzymes that detoxify carcinogens. Proc Natl Acad Sci USA 1995;92:8965-9.

[39] Witt O, Monkemeyer S, Ronndahl G, Erdlenbruch B, Reinhardt D, Kanbach K, Pekrun A. Induction of fetal hemoglobin expression by the histone deacetylase inhibitor apicidin. Blood 2003;101: 2001-7.

[40] Darkin-Rattray SJ, Gurnett AM, Myers RW, Dulski PM, Crumley TM, Allocco JJ, Cannova C, Meinke PT, Colletti SL, Bednarek
MA, Singh SB, Goetz MA, Dombrowski AW, Polishook JD, Schmatz DM. Apicidin: a novel antiprotozoal agent that inhibits parasite histone deacetylase. Proc Natl Acad Sci USA 1996;93: 13143-7.

[41] Han JW, Ahn SH, Park SH, Wang SY, Bae GU, Seo DW, Kwon HK, Hong S, Lee HY, Lee YW, Lee HW. Apicidin, a histone deacetylase inhibitor, inhibits proliferation of tumor cells via induction of p21WAF1/Cip1 and gelsolin. Cancer Res 2000;60:6068-74.

[42] Park JI, Choi HS, Jeong JS, Han JY, Kim IH. Involvement of p38 kinase in hydroxyurea-induced differentiation of K562 cells. Cell Growth Diff 2001;12:481-6.

[43] Baliga BS, Pace BS, Chen HH, Shah AK, Yang YM. Mechanism for fetal hemoglobin induction by hydroxyurea in sickle cell erythroid progenitors. Am J Hematol 2000;65:227-33. 